\title{
Characteristics of fluid inclusions in the Cenozoic volcanic-hosted Kushk-e-Bahram Manto-type Cu deposit of central Iran
}

\author{
Marjan Jebeli ${ }^{1}$, Peyman Afzal ${ }^{2 *}$, Mohsen Pourkermani $^{3}$, Alireza Jafarirad ${ }^{4}$ \\ ${ }^{1}$ Department of Geology, North Tehran Branch, Islamic Azad University, Tehran, Iran; Jebeli_marjan@yahoo.com \\ ${ }^{2}$ Department of Petroleum and Mining Engineering, South Tehran Branch, Islamic Azad University, Tehran, Iran; \\ P_Afzal@azad.ac.ir \\ ${ }^{3}$ Department of Geology, North Tehran Branch, Islamic Azad University, Tehran, Iran; \\ Mohsen.pourkermani@gmail.com \\ ${ }^{4}$ Department of Science and Research Branch, Islamic Azad University, Tehran, Iran; Alirad@yahoo.com \\ *corresponding author, e-mail address: P_Afzal@azad.ac.ir
}

\begin{abstract}
The Kushk-e-Bahram Manto-type Cu deposit is located in central Iran, within Eocene to Oligo-Miocene volcanic strata which occur in the central part of the Uremia-Dokhtar Magmatic Arc (UDMA). Propylitization, silicification, argillization and carbonatization are the main types of alteration to have affected the pyroclastic and volcanic rocks. There are high amounts of oxide minerals, including malachite, azurite, hematite, magnetite and goethite. Three types of primary FIs have been determined in the Kushk-e-Bahram deposit, namely; I: two-phase liquid-rich FIs (L+V), II: mono-phase liquid FIs, III: two-phase vapour-rich FIs which have been identified based on petrographical studies. Based on FI studies of co-existing quartz and calcite, homogenization temperatures (Th) must have been between 67 and $228^{\circ} \mathrm{C}$, with an average of $158^{\circ} \mathrm{C}$. Moreover, salinity is between 14.0-30.3 wt $\% \mathrm{NaCl}$, equivalent to a $19.6 \%$ average. Fluid density values vary from 0.8 to $1.1 \mathrm{gr} / \mathrm{cm}^{3}$. Based on FI data and related diagrams, the depth of their trapping was estimated to be $<200 \mathrm{~m}$ and ore formation occurred at pressures of $<50$ bars. Consequently, mineralogy, host rock and FIs characteristics in the Kushk-e-Bahram deposit are similar to the Manto-type Cu deposits in Mesozoic-Cenozoic volcanic belts of Iran and South America.
\end{abstract}

Key words: Fluid inclusion (FI), salinity, homogenization temperatures (Th), copper

\section{Introduction}

Iran consists of several structural/metallogenic belts that host world-class metallic deposits, especially $\mathrm{Cu}$. The major Iranian $\mathrm{Cu}$ mineralized belt is the Uremia-Dokhtar Magmatic Arc (UDMA) with an extension between the northwesterly and southeasterly parts of the country (Berberian \& King, 1981; Alavi, 1994). It hosts porphyry-Cu deposits such as Sar-Cheshmeh, Meiduk, Darreh-Zar, Dar- ralou, Baghkhooshk, Kuhpanj and Sarkuh (McInnes et al., 2005; Alipour-Asll, 2019) and related types of copper mineralization types, especially Manto-type $\mathrm{Cu}$ deposit and vein mineralization (Aghazadeh et al., 2015; Rezaei et al., 2015; Jebeli et al., 2018). However, volcanic-hosted, strata-bound $\mathrm{Cu}$ deposits named "Manto type" are explored in many parts of the UDMA and other structural zones, as depicted in Figure 1 (Samani, 1998; Boveiri et al., 2013; Abolipour et al., 2015; Maghfouri \& Movah- 
ednia, 2015; Salehi \& Rasa, 2016; Rajabpour et al., 2017). The Manto-type deposits have high-grade $\mathrm{Cu}$ and are suitable for ore excavation. Since 2000, many Manto-type $\mathrm{Cu}$ deposits have been studied and explored such as Buena Vista, Susana-Linace, Mantos de La Luna and El Soldado in Chile (Boric et al., 2002; Kojima et al., 2003, 2009). These deposits are the second largest copper resources of Chile, after its huge porphyry-Cu deposits (Wilson \& Zentilli, 2006). Campus (1980) differentiated Mesozoic Manto-type $\mathrm{Cu}$ mineralization into two classes, including sediment-hosted (e.g., Carrillo-Rosua et al.,
2014) and volcanic-hosted (e.g., Wilson \& Zentilli, 2006; Ramirez et al., 2006).

The most important Iranian Manto-type $\mathrm{Cu}$ deposits are the Kesht Mahaki (Boveiri et al., 2013), Abbas-Abad (Maghfouri \& Movahednia, 2015; Salehi \& Rasa, 2016), Veshnaveh, Kashkouieh, Kuh-Pang and Narbaghi in the UDMA (Abolipour et al., 2015; Fazli et al., 2015; Rajabpour et al., 2017), Varzag (Alizadeh et al., 2013) and Ghare-Tappeh (Karami \& Afzal, 2015), Mari (Maghfouri et al., 2016) and Kushk-e-Bahram (Jebeli et al., 2018) (Fig. 1). The Iranian Manto-type $\mathrm{Cu}$ deposits occur inside Eocene volca-
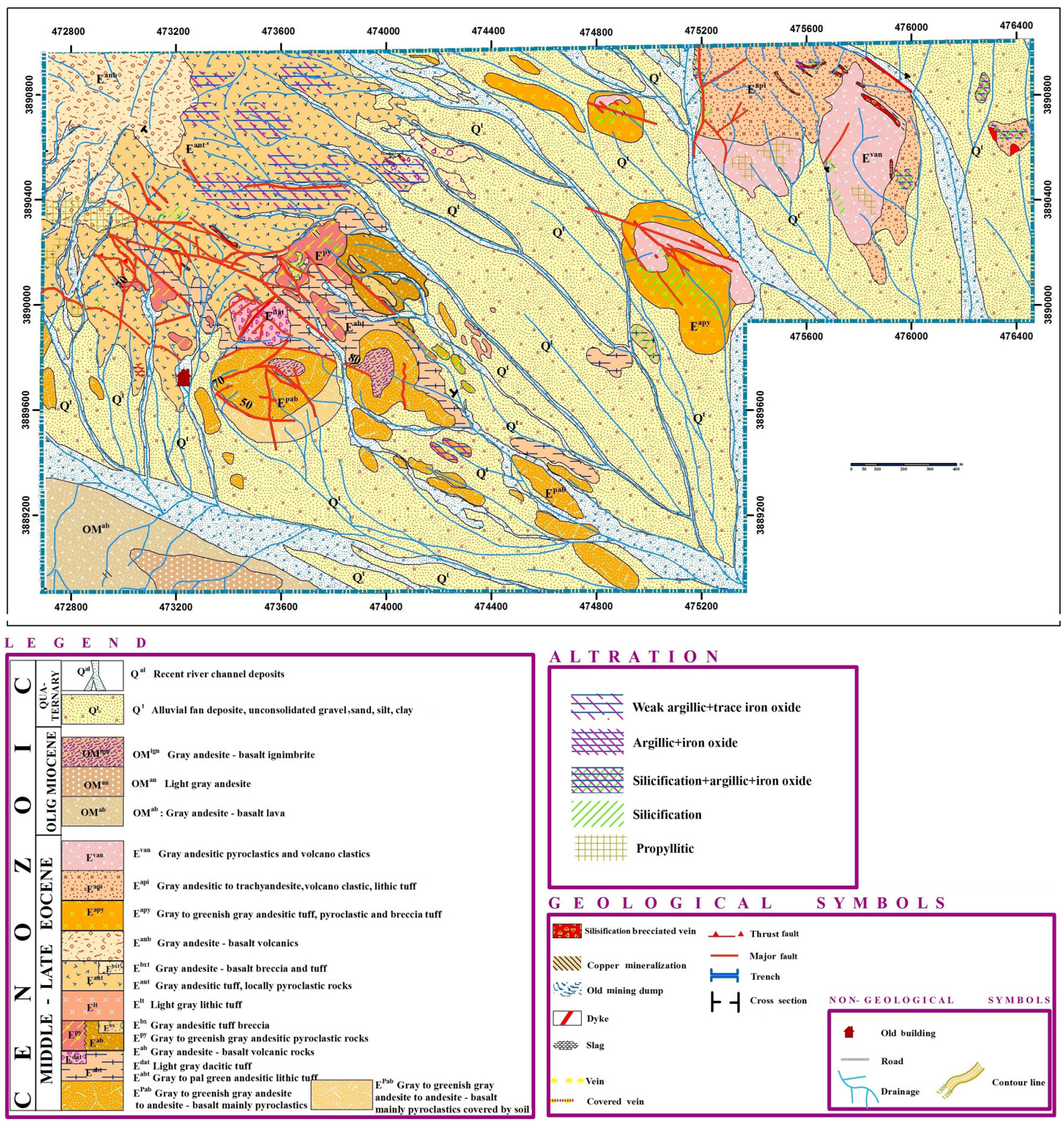

Fig. 1. Geological map of the Kushk-e-Bahram deposit (by Kazemi Mehrnia, 2012) 
no-sedimentary sequences. The Eocene-Oligocene volcanic lithology in the Saveh district, about 104 $\mathrm{km}$ southwest of Tehran, hosts several $\mathrm{Cu}$ deposits within the NW-SE belt (Samani, 1998; 2003; Ghaderi et al., 2016) (Fig. 1).

Fluid Inclusion (FI) studies are essential tools for determination of the physicochemical conditions of the ore-forming processes in various copper deposits (Beane \& Bodnar, 1995; Richards, 2015). In the present paper, data obtained from FIs have been collected and analysed for micro-thermometric characteristics in the Kushk-e-Bahram strata-bound deposit. The results obtained by FI have been interpreted and compared with other Manto-type $\mathrm{Cu}$ deposits in Iran and Latin America. The purpose of the present study is to determine ore genesis and hydrothermal evolution of the Kushk-e-Bahram Cu deposit on the basis of fluid inclusion studies and correlation with ore mineralogy, ore texture and structure and alteration zones.

\section{Regional geological setting and geology of the Kushk-e-Bahram deposit}

\subsection{Geological characteristics}

The UDMA is composed mainly of voluminous volcanic successions with minor intrusions that were emplaced during the Neo-Tethyan subduction under the Central Iranian Terrain (Berberian \& King, 1981; Alavi, 1994; McQuarrie et al., 2003). The UDMA is part of the Alpine-Himalayan orogenic belt which is connected to the magmatic belts in Turkey and Pakistan (Shafiei et al., 2009; Haschke et al., 2010; Aghazadeh et al., 2015; Richards, 2015; Imer et al., 2016).

Most of the volcano-plutonic rocks in the UDMA were formed during the Late Paleocene and Late Eocene (McQuarrie et al., 2003; Zarasvandi et al., 2015). This magmatic belt contains andesites, trachy-andesites, subordinate basalts, latites, dacites and intrusive rocks consisting of monzonite, granodiorite, quartz diorite and quartz monzonite with ages between 50-35 Ma (Alavi, 1994; Richards, 2015).

This belt hosts the main porphyry deposits of Iran, in particular Sarcheshmeh, Sungun, Meiduk and Kahang (e.g., Shahabpour \& Kramers, 1987; Hezarkhani, 2006; Afzal et al., 2010; Richards, 2015; Alirezaei et al., 2017). However, there are other types of copper deposits such as epithermal, copper veins and Manto-type deposits, especially in the UDMA central section. Many plutonic/volcanic bodies exist in the Saveh region and the central part of the UDMA (Rezaei-Kahkhaei et al., 2011; Rezaei et al., 2015; Rajabpour et al., 2017). There are several Manto-type $\mathrm{Cu}$ occurrences within the volcanic and pyroclastic rocks.

\subsection{Geology of the Kushk-e-Bahram deposit}

Copper mineralization in the Kushk-e-Bahram deposit occurs as veins within Eocene-Oligocene volcanic rocks hosted by pyroclastic and andesitic units (Jebeli et al., 2018). The main mineralized veins are hosted by andesites and rhyolites. The geological characteristics of the Kushk-e-Bahram deposit, including its host rocks, mineralization geometry, ores and hydrothermal alteration zones resemble Manto-type Cu mineralization elsewhere in the Saveh region (Rajabpour et al., 2017; Jebeli et al., 2018). Several works, inclusive of geological map generation, XRD and XRF analysis, petrographical and mineralographical studies, have been carried out in this area. In the past, there were some smallscale mining activities; currently, exploration is under way. In addition, there are nine boreholes for subsurface exploration (Jebeli et al., 2018).

On the basis of geological data, including surface and subsurface data for this deposit, the main rock types are pyroclastic tuff, andesite tuff and pyroclastic andesites (Fig. 1). The quartz-suphide veins are small and include chalcopyrite, pyrite and bornite, whereas the gangue minerals include calcite, quartz, chlorite and sericite. In addition, oxidized copper ores, characterised by malachites and minor azurite, occurs in veins in this area. Ore textures include microgranular, intergranular, porphyritic, glomeroporphiritice, microporphyritic, microlithic, spheroidal, vein-veinlet, open-space filling, replacement and laminated, coloidal and comb textures.

This Manto-type $\mathrm{Cu}$ deposit occurs within Eocene-Oligocene volcanic rocks of the UDMA and regional faults consisting of the Takhte-Chaman, Abbas-Abad and Kushk-e-Nosrat affected this mineralization (Fig. 1). The trend of the major faults is WNW to ESE, with several associated small faults trending NW to SE (Amidi et al., 2006).

\subsection{Mineralization}

The Kushk-e-Bahram deposit is strata bound and occurs within the upper member of the Eocene volcanic series. $\mathrm{Cu}$ and Ag means are equal to $6310 \mathrm{ppm}$ and 0.263 ppm, respectively (Jebeli et al., 2018). Major ore minerals are chalcopyrite, chalcocite, bornite, covellite and digenite. Main and high-grade ore bodies 
are related to hydrothermal breccias which are associated with silicic and argillic alteration zones. These breccias consist of hydrothermal features with a matrix that is composed mainly of ore/gangue minerals and altered angular to subrounded rhyodacite fragments (Fig. 2F). Low-grade copper mineralization extends from structures into the altered host rocks as fillings of voids. Three mineralization stages have been recognised in the Kushk-e-Bahram deposit. In the first stage, pyrite formed under decreasing conditions in the host rock. In the main mineralization (i.e., second) stage, pyrite was replaced by primary copper sulphide minerals such as chalcopyrite and bornite. Finally, in the third (supergene) stage, copper sulphide minerals were replaced by secondary copper sulphide minerals (chalcocite, covellite and digenite) and oxide minerals (malachite, azurite, goethite and hematite).

\subsection{Alteration}

The main mineralized zones are associated with high intensity silicification which extends into the rhyolitic and andesitic rocks. Silicification consists of quartz and local advanced argillic alteration. They are surrounded by an intermediate argillic alteration zone. These quartzs consist of a groundmass of microcrystalline anhedral to subhedral grains with disseminated pyrite, chalcopyrite and bornite (Fig. 2A-C). The argillic alteration including kaolinite, pyrophyllite and dickite, is extensive within the mineralized zones. This generated secondary porosity in the form of irregular voids and cavities, which are generally infilled by alunite, pyrite, chalcopyrite, bornite and barytes (Fig. 2D). Petrographical studies show that this material is an admixture of alunite with quartz, dickite and kaolinite/pyrophyllite. There are hydrothermal disseminations of secondary quartz crystals with comb texture and quartz aggregates were replaced instead of feldspar phenocrysts (Fig. 2E). Carbonatization alteration developed in the form of both carbonate veins and fine-grained disseminated carbonates in all host rocks (Fig. 2F). Propylitic alteration is present throughout the Kushk-e-Bahram deposit with replacement of mafic minerals by chlorite, as depicted in Figure 2F.

\subsection{Paragenetic sequence}

The initial hydrothermal activity included argillic alteration and deposition of pyrites and chalcopy-
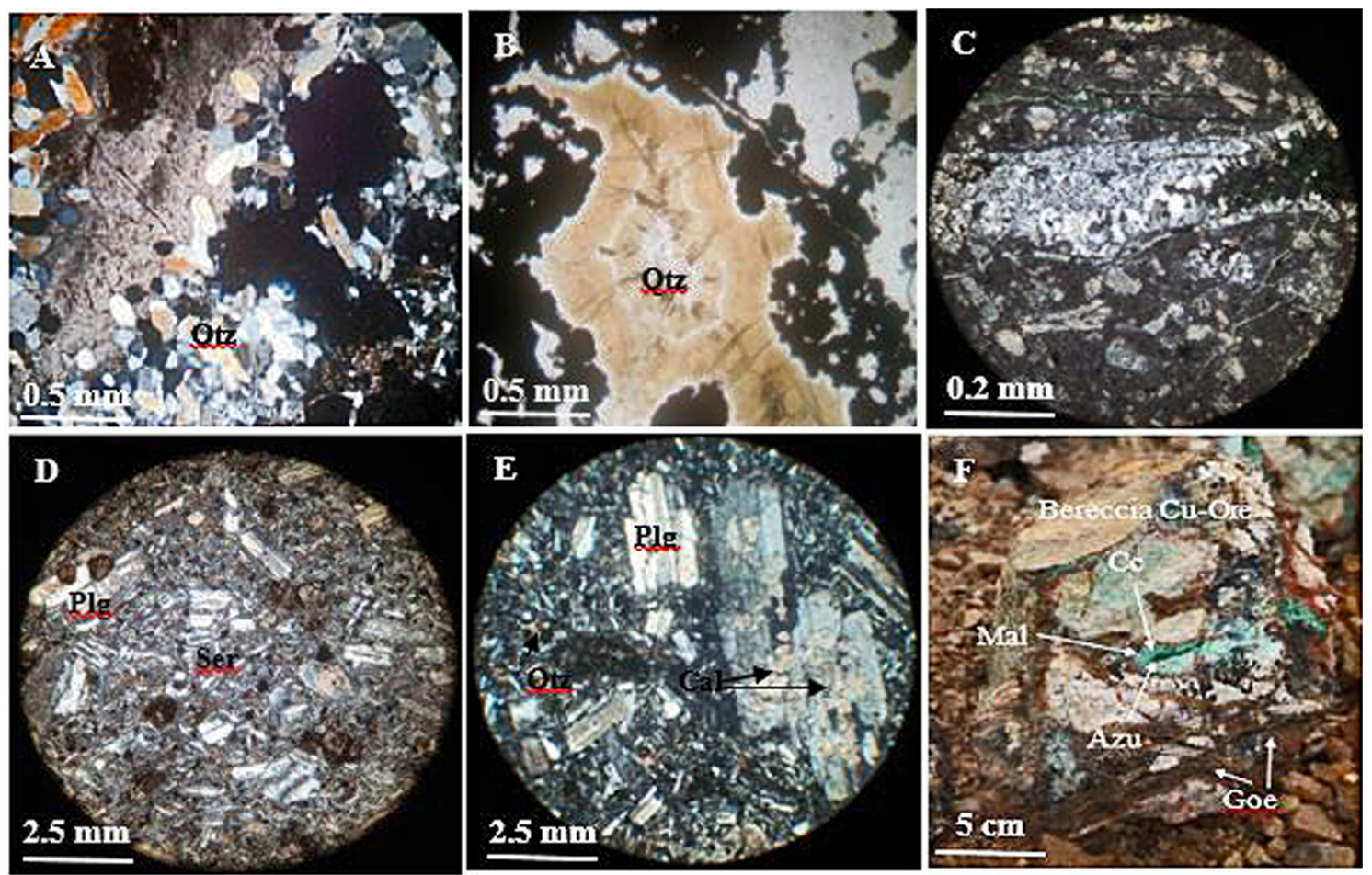

Fig. 2. A - Association of intergranular quartz grains with disseminated pyrite and chalcopyrite; B - Quartz crystals in vesicular texture; C - Secondary quartz crystals in comb texture; D - Fine-grained sericite crystals along fractures with pyrite and chalcopyrite; E, F - Replacement of plagioclase crystal with calcite. Abbreviations: Cal = calcite, $\mathrm{Cc}=$ chalcocite, $\mathrm{Goe}=$ goethite, $\mathrm{Plg}=$ plagioclase, $\mathrm{Qtz}=$ quartz, Ser $=$ sericite, $\mathrm{Azu}=$ azurite 
Table 1. Mineral assemblages and paragenetic sequence in the Kushk-e-Bahram deposit

\begin{tabular}{|c|c|c|c|c|c|c|}
\hline \multirow{3}{*}{\multicolumn{2}{|c|}{ Minerals/Texture }} & $\begin{array}{c}\text { Pre- } \\
\text { Mineralization }\end{array}$ & \multicolumn{2}{|c|}{ Mineralization } & \multicolumn{2}{|c|}{ Post-Mineralization } \\
\hline & & \multirow{2}{*}{ Volcanism } & \multicolumn{2}{|c|}{ Diagenesis } & \multicolumn{2}{|c|}{ Supergene } \\
\hline & & & Early & Late & Sulphide & Oxide \\
\hline \multirow{13}{*}{ 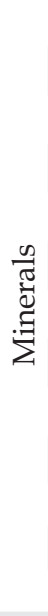 } & Bornite & & & & & \\
\hline & Chalcocite & & & & & \\
\hline & Chalcopyrite & & & & & \\
\hline & Covellite & & & & & \\
\hline & Digenite & & & & & \\
\hline & Hematite & & & & & \\
\hline & Azurite & & & & & \\
\hline & Malachite & & & & & \\
\hline & Zeolite & & & & & \\
\hline & Calcite & & & & & \\
\hline & Chlorite & & & & & \\
\hline & Pyrite & & & & & \\
\hline & Silica & & & & & \\
\hline \multirow{4}{*}{ 窇 } & Disseminated & & & & & \\
\hline & Vein-Veinlet & & & & & \\
\hline & $\begin{array}{l}\text { Open Space } \\
\text { Filling }\end{array}$ & & & & & \\
\hline & Replacement & & & & & \\
\hline
\end{tabular}

rites. The chalcopyrite replaced pre-existing pyrite and also it was replaced by $\mathrm{Cu}$-rich ores especially bornite and chalcocite at this stage. The major mineralization stage was followed by an overprint of the propylitic alteration zone. The process of supergene enrichment created an extensive replacement of sulphidic copper minerals by malachite, azurite and oxidic copper ores (Jebeli et al., 2018) (Table 1).

\section{Analytical methods}

In the present study, fluid inclusion (FI) micro-thermometric characteristics have been analysed on the basis of eight samples collected from the silicic ore-bearing veins of drill cores in the Kushk-e-Bahram deposit. Eight double-polished sections (100 $\mu \mathrm{m}$ thickness) have been selected as based on sulphide-quartz veins in cores within andesitic and pyroclastic rocks. These samples have been prepared for micro-thermometric analysis in order to achieve a preliminary estimate of the temperatures and salinities of the ore-forming fluid. Conventional methods (Roedder, 1971) and a Linkam THMS 600 heating-freezing stage (between $-196^{\circ} \mathrm{C}$ and $+600{ }^{\circ} \mathrm{C}$ ) installed on an Olympus TH4-200 microscope stage have been used in the Mineral Processing Research Centre (IMPRC) at Karaj (Iran). The precision is estimated to be $\pm 0.2^{\circ} \mathrm{C}$ on freezing, \pm $2^{\circ} \mathrm{C}$ below $-94.3^{\circ} \mathrm{C}$ and about $\pm 6^{\circ} \mathrm{C}$ above $+414^{\circ} \mathrm{C}$ for heating. This stage has been calibrated at low temperatures with n-Hexane $\left(-94.3^{\circ} \mathrm{C}\right)$ and calibration at $\left(+414^{\circ} \mathrm{C}\right)$ by Cesium nitrate. The FI salinity was calculated by the final ice melting temperature (Tm $\left.{ }_{\text {ice }}\right)$ and formula of Bodnar (1993).

\section{Discussion and results}

\subsection{Fluid inclusion types and occurrence}

Roedder (1984) and Shepherd et al. (1985) classified FIs into primary, secondary and pseudo-secondary. The FIs formed in quartz crystals were delineated both as primary in origin, and secondary occurring in micro-fractures of the quartz veins which collected from mineralized cores (Roedder, 1984; Esmaeli et al., 2015). The results obtained by petrographical data, microthermometric studies and phases detected at room temperatures indicate three types of Fis in these samples. These samples have been collected from andesitic and rhyolitic rocks with sulphidic minerals, including pyrite, chalcopyrite, covellite and chalcocite. The FIs types are expressed in the following forms (Fig. 3):

- I: two-phase liquid-rich (L + V)

- II: mono-phase liquid

- III: two-phase vapour-rich $(\mathrm{V}+\mathrm{L})$. 

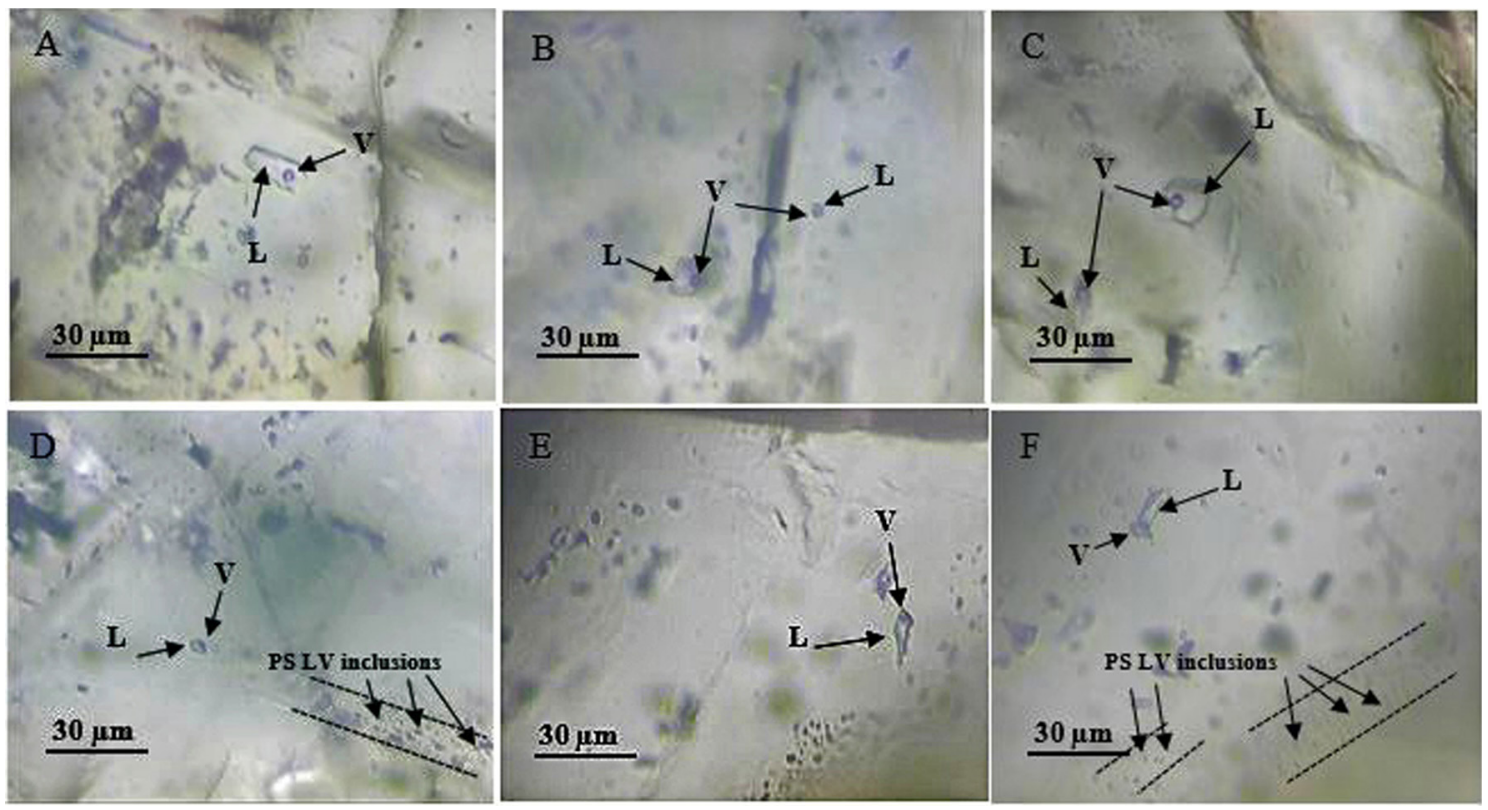

Fig. 3. Photomicrographs of fluid inclusion assemblages (FIs) of the three stages of mineralization (at room temperatures, in plane-polarized light)

A - Primary two-phase liquid-rich ( $>$ > V) FIs hosted by quartz; B, C - Co-existing primary vapour- and liquid-rich FIs in quartz, indicating boiling; D - Densely distributed pseudo-secondary liquid-rich type inclusions restricted to recrystallized quartz and primary two-phase liquid-rich (L > V) FIs; E - Primary two-phase liquid-rich fluid inclusion hosted by quartz; F - Pseudo-secondary liquid-rich type inclusions trapped in quartz (L > V) FIs. Abbreviations: $\mathrm{L}=$ liquid, $\mathrm{V}$ = vapour, $\mathrm{PS}=$ pseudo-secondary fluid inclusions

Type I FIs are more abundant $(\approx 85 \%)$ than the other types in the quartz veins of the study area. The liquid volume of type I FIs are between 75 and $80 \%$ of their content. The FIs featured in both irregular and regular shapes such as ellipsoids with sizes of 5-20 $\mu \mathrm{m}$ (maximum dimension) without any differences for salinity, homogenization temperatures and gas/liquid ratio.

\subsubsection{Fluid inclusion petrography}

The Fluid Inclusion Assemblage (FIA) method is applied on quartz $(\mathrm{Qz})$ samples in order to calculate temperatures during formation of the deposit. Two types of Fis have been investigated in the Kushk-e-Bahram deposit: liquid-rich (LV) and vapour-rich $(\mathrm{VL})$ at room temperatures, without detectible $\mathrm{CO}_{2}$ or $\mathrm{CH}_{4}$. Primary FIs are scattered along growth zones and denote the fluid from which the host mineral precipitated, as depicted in Figure 3. Inclusions introduced to be pseudo-secondary FIs are inaccessible or existed in clusters along trails in random distribution. Furthermore, these FIs occurred within crack planes that end abruptly against grain boundaries (Fig. 3A-F). About $90 \%$ of the FIs are of the LV type. They were generated in rounded shapes and negative crystal in many cases but some of them have polygonal shapes, including irregular to tabular, as illustrated in Figures
3A-B. The LV inclusions, with 60 to $90 \mathrm{vol} \%$ of liquid at room temperatures, homogenise to a liquid phase. The LV type has been observed in quartz and calcite. A co-existence of the VL and LV types would indicate that boiling occurred generally, as depicted in Figure 3D-F. Micrometric measurements have been performed on the LV FIs. It shows necking down and leakage which did not occur and had almost the same ratio. The VL inclusions contain $70-90$ vol\% vapour bubbles with rounded shapes (oval and elongate), ranging in sizes between 5 and $25 \mu \mathrm{m}$ inclusion and homogenise to a vapour phase.

\subsection{Microthermometry results}

The Fis of Type I were homogenised to a liquid state at temperatures between 67 and $228^{\circ} \mathrm{C}$ (with a mean of $158^{\circ} \mathrm{C}$ ), as documented in Table 2 and Figure 4 . The salinity values varied between 14.0 and $30.3 \mathrm{wt} \%$ equivalent of $\mathrm{NaCl}$ (see Fig. 5). The first ice melting temperatures (Te) were between -45 and $-60^{\circ} \mathrm{C}$, with a mean of $-54^{\circ} \mathrm{C}$. Based on these temperatures, these $\mathrm{Te} / \mathrm{Tfm}$ data do not reflect the $\mathrm{H}_{2} \mathrm{O}-\mathrm{NaCl}$ system. The Te of $\mathrm{H}_{2} \mathrm{O}-\mathrm{NaCl}$ is $-21.2^{\circ} \mathrm{C}$. Furthermore, below $-49^{\circ} \mathrm{C}$ the dominant components are $\mathrm{Mg}$ and $\mathrm{Ca}$, which accompany $\mathrm{Na}$ (Shep- 


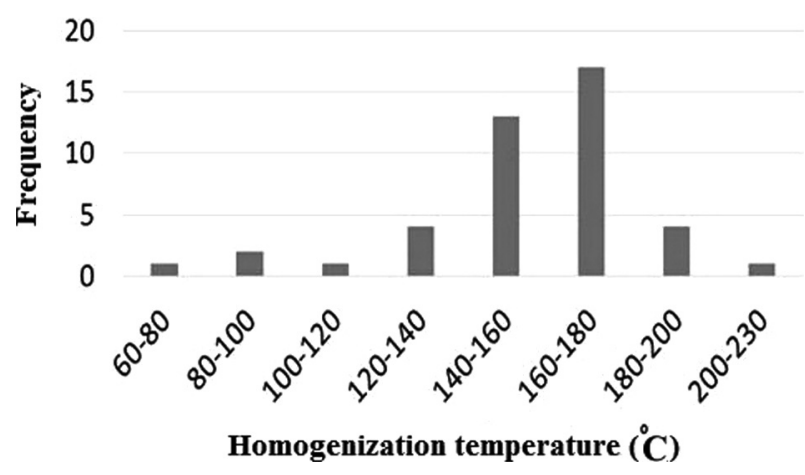

Fig. 4. Histogram of homogenization temperatures of fluid inclusions in quartz of the Kushk-e-Bahram deposit

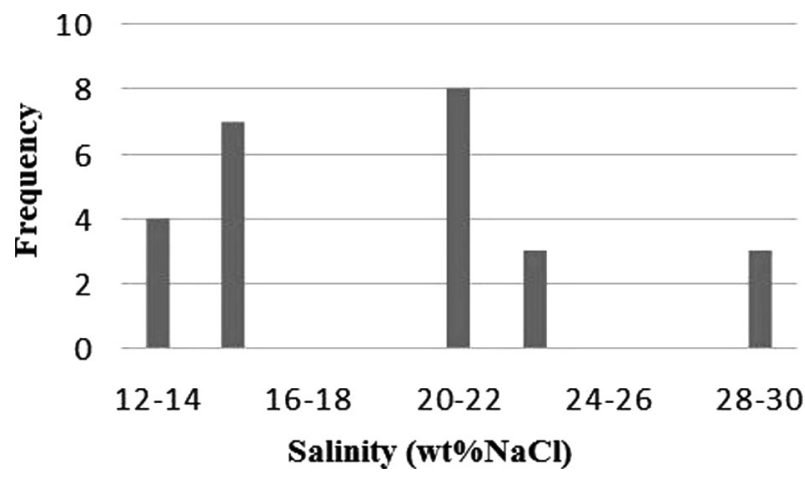

Fig. 5. Histogram of salinity of fluid inclusions in quartz of the Kushk-e-Bahram deposit

Table 2. Microthermometric results of FIs from the Kushk-e-Bahram Cu deposit

\begin{tabular}{cccccccc}
\hline Host mineral & Size $(\mu \mathrm{m})$ & Type & Origin & $\mathrm{T}_{\mathrm{e}}$ & $\mathrm{T}_{\mathrm{m}}$ & $\mathrm{T}_{\mathrm{h}}$ & Salinity $(\mathrm{wt} \% \mathrm{NaCl})$ \\
\hline Quartz & $5-35$ & Liquid+vapor & Primary & -45 to -60 & -10 to -42.5 & $67-228$ & $13.9-30.29$ \\
\hline
\end{tabular}

herd et al., 1985). Furthermore, this temperature is close to eutectic temperatures of $\mathrm{H}_{2} \mathrm{O}-\mathrm{NaCl}-\mathrm{CaCl}_{2}$ (Shepherd et al., 1985). In addition, these Te values have revealed the presence of $\mathrm{Na}^{+}$and $\mathrm{Ca}^{2+}$ as major cations in the ore-forming fluid with $\mathrm{Cu}^{2+}$. Type II inclusions are very low in samples; there are no microthermometric data.

\subsection{Evolution path of ore-forming fluids and deposition mechanism}

Mixing and boiling processes can be introduced as major factors in controlling fluid evolution for ore deposition in this deposit (Fig. 6). One of the essential pieces of evidence for boiling is the existence of FIS of types I and III in these samples (Roedder, 1984; Calagari, 2004; Yao et al., 2012). Moreover, flu-



Fig. 6. Correlation between salinity and homogenization temperature, showing boiling and isothermal mixing for ore-forming processes id mixing (Simmons et al., 2005) and cooling (Ulrich et al., 2002; Redmond et al., 2004) could be another important factor for copper deposition based on a high range of salinities and Th (Oyarzun et al., 1998; Wang et al., 2013). Based on homogenization temperatures (Th) and salinities, the density of fluids varied between 0.8 and $1.1 \mathrm{gr} / \mathrm{cm}^{3}$ and increased in direct relationship with salinity values (Roedder, 1984).

The boiling represented by microthermometric data in ore fluids is crucial for the determination of predominant pressure and temperature during the ore formation process. Low temperatures have been detected in a quartz sample as 67,83 and $89^{\circ} \mathrm{C}$. Furthermore, mono-phase fluid inclusion associated with necking off has been seen in a single sample only; this is not proper for detection of temperature. The total pressure determined from fluid inclusion may be hydrostatic, derived via the weight of the column of overlying fluid. This pressure can be lithostatic, as obtained by the weight of the overburden. The pressure for aqueous inclusions with a $\mathrm{NaCl}$ solution was discussed by Roedder (1980). Vapour pressure for fluid has been determined to be less than 50 bars, according to the wt $\%$ of salinity and Th diagram (Ramdohr, 1980) (Fig. 7A). The fluids with low pressure indicate most likely a shallow environment under hydrostatic conditions. However, the depth of entrapment of Fis is lower than 200 metres, as based on the diagram of Haas (1971) (see Fig. 7B). If fluid denotes boiling conditions, assuming a hydrological system that is accessible to the surface, vapour pressure can be used to estimate the trapping depth, as shown in Figure 2. Based on this assumption, the depth of the FIs trapping is lower than 200 metres. 



Fig. 7. A - Diagrams for vapour pressure of FIs on the basis of salinity and homogenization temperature (graph from Romdohr, 1980); B - Depth of FIs trapping (graph from Hass, 1971)

\subsection{Comparison between FI characteristics of Kushk-e-Bahram and Manto-type $\mathrm{Cu}$ deposits}

At this stage, the particulars of the FIs from the deposit studied are compared with several Manto-type $\mathrm{Cu}$ deposits in Iran and Latin America, in- cluding Madan Bozorg in northeast Iran (Salehi \& Rasa, 2016) and Chilean deposits including Buena Vista, El Soldado, Suasana-Lince and Mantos de la lona (Boric et al., 2002; Kojima et al., 2003, 2009) (Fig. 8; Table 3). The homogenization temperature in Manto-type $\mathrm{Cu}$ deposits changes from $64^{\circ}$ to $601^{\circ}$ (Kojima et al., 2003); these deposits have low pressure conditions close to the boiling curve. Evidence

Table 3. Comparison of the Kushk-e-Bahram Cu deposit and Chilean Manto-type deposits

\begin{tabular}{|c|c|c|}
\hline Deposit characteristics & Chilean Manto-type Cu deposits & Kushk-e-Bahram Cu deposit \\
\hline Age of sequence & Jurassic - Lower Cretaceous & Late Eocene \\
\hline Tectonic setting & Back-arc basins, island-arc, continental-arc & Back-arc basins \\
\hline Depositional environment & Shallow marine, submarine, subaerial & $\begin{array}{l}\text { Shallow marine, submarine, volca- } \\
\text { nic }\end{array}$ \\
\hline Age of mineralization & Epigenetic & Epigenetic \\
\hline Host/associated rock types & Amygdaloidal andesite flow, basaltic lava & $\begin{array}{l}\text { Andesitic basalt, andesitic tuff and } \\
\text { rhyolite, tuff, latite andesite }\end{array}$ \\
\hline Deposit form & $\begin{array}{l}\text { Vein-veinlets, strata-bound (restricted to particu- } \\
\text { lar units) }\end{array}$ & $\begin{array}{l}\text { Strata-bound, vein-veinlets restrict- } \\
\text { ed to andesite, but discordant to the } \\
\text { strata }\end{array}$ \\
\hline Texture & $\begin{array}{l}\text { Disseminations, open-space fillings, veins and } \\
\text { replacement textures }\end{array}$ & $\begin{array}{l}\text { Disseminations, open-space fillings, } \\
\text { veins and replacement }\end{array}$ \\
\hline Ore mineralogy & $\begin{array}{l}\text { Chalcocite, bornite, chalcopyrite, pyrite, hema- } \\
\text { tite, native copper }\end{array}$ & $\begin{array}{l}\text { Pyrite, chalcopyrite, chalcocite, cov- } \\
\text { ellite, bornite, , hematite }\end{array}$ \\
\hline Gangue mineralogy & $\begin{array}{l}\text { Calcite, quartz, epidote, hematite, chlorite and } \\
\text { zeolite }\end{array}$ & $\begin{array}{l}\text { Calcite, quartz, epidote, hematite, } \\
\text { chlorite (zeolite) }\end{array}$ \\
\hline Alteration & $\begin{array}{l}\text { Silicification, sericitization, proplylitic and car- } \\
\text { bonates }\end{array}$ & $\begin{array}{l}\text { Proplylitic, argillic, sericitization, } \\
\text { carbonates }\end{array}$ \\
\hline Genesis & $\begin{array}{l}1 \text { - Syngenetically formed volcanogenic deposits; } \\
2 \text { - Epigenetically formed by magmatic emana- } \\
\text { tion of associated plutonic intrusions; } \\
3 \text { - Epigenetic - diagenetic }\end{array}$ & Epigenetic - diagenetic \\
\hline Homogenization & $64-601^{\circ} \mathrm{C}\left(150-300^{\circ} \mathrm{C}\right)$ & $67-228^{\circ} \mathrm{C}\left(158^{\circ} \mathrm{C}\right)$ \\
\hline Salinities & $1.5-62(15-30)$ & $14.0-30.3(15-30)$ \\
\hline References & $\begin{array}{l}\text { Wilson et al. (2003); Wilson \& Zentilli (2006); } \\
\text { Kojima et al. (2009) }\end{array}$ & Jebeli et al. (2017); this study \\
\hline
\end{tabular}


of boiling has also been observed in Manto-type deposits. The salinity of these deposits is between 1.5 and $62 \mathrm{wt} \%$ equivalent of $\mathrm{NaCl}$. The Kushk-e-Bahram $\mathrm{Cu}$ deposit indicates homogenization temperatures between 67 and $228^{\circ} \mathrm{C}$ (with a mean of $158^{\circ} \mathrm{C}$ ) and the salinity values vary between 14 and 30.3 wt $\%$ equivalent of $\mathrm{NaCl}$. Based on salinity and $\mathrm{Th}$ values, the Kusk-e-Bahram copper deposit is similar to Madan Bozorg and El Soldado, which are volcanic-hosted Manto-type $\mathrm{Cu}$ deposits (Fig. 8). The Th and salinity values of Kusk-e-Bahram deposit is like that of the Chilean deposits (see Table 3).

Most microthermometric data of fluid inclusions from the Kushk-e-Bahram deposit plot in the basinal fluid field (compare Kesler, 2005) (Fig. 9). Therefore, the source can be the basinal fluid that led to copper mineralization by leaching the volcanic rocks in the area.

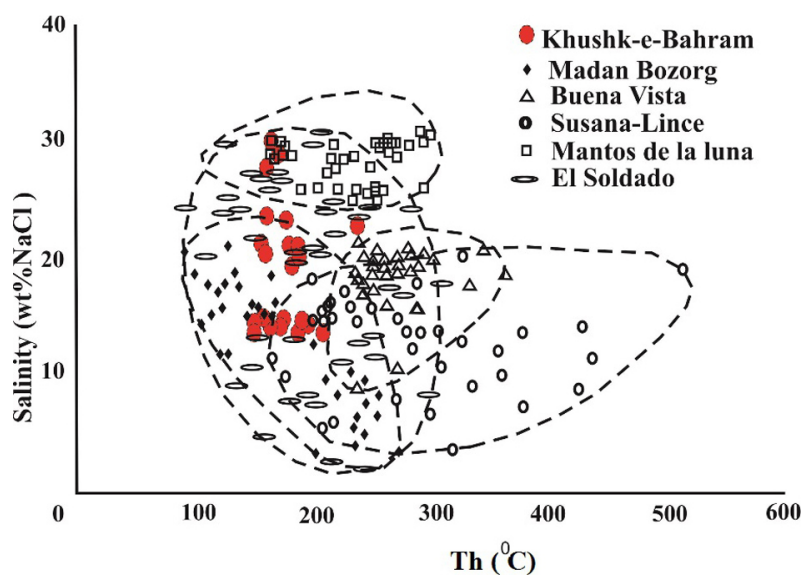

Fig. 8. Salinity and homogenization temperature (Th), illustrating the distribution pattern of data points in the Kushk-e-Bahram deposit (red dots). Comparison with Iranian and Chilean Manto-type deposits (Boric et al., 2002; Kojima et al., 2003, 2009; Salehi \& Rasa, 2016)

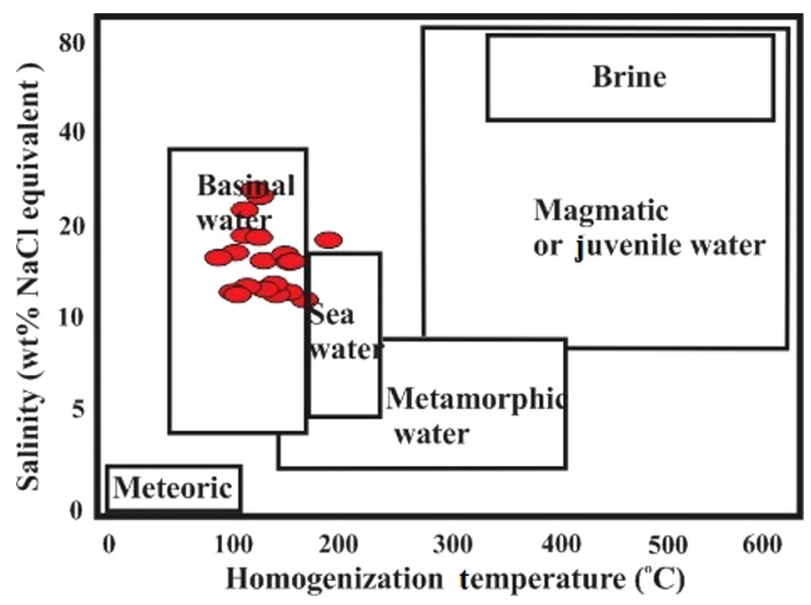

Fig. 9. Homogenization temperature/salinity diagram illustrating mineralizing fluids in the Kushk-e-Bahram deposit (areas of genetic factors by Kesler, 2005)

\section{Conclusions}

The Kushk-e-Bahram Manto-type $\mathrm{Cu}$ deposit is strata bound and occurs in the central part of Uremia-Dokhtar Magmatic Arc. The copper deposit contains ore-bearing quartz veins in Eocene to Oligo-Miocene pyroclastic and volcanic rocks, especially tuffs and andesitic units. The main sulphide minerals are chalcopyrite, pyrite, bornite, chalcocite and covellite, which are accompanied by hematite. In the early stage of mineralization, pyrite formed in a reduction state in the host rock. In the main mineralization stage, pyrite was replaced by primary copper sulphide minerals such as chalcopyrite and bornite. Finally, copper sulphide minerals were replaced by secondary copper sulphide minerals and oxide minerals in the supergene stage. FIs data indicate homogenization temperatures of 67 to $228^{\circ} \mathrm{C}$ with an average of $158^{\circ} \mathrm{C}$ and a salinity range between 13.99 and 30.29 (average, 19.5) wt\% $\mathrm{NaCl}$ equivalent, with pressure and trapping depth lower than 50 bars and 200 metres, respectively. The results obtained by the FIs indicate that boiling and mixing can be the main factors for controlling of quartz and sulphide mineral precipitation. Fluid mixing could also have occurred, particularly in the late mineralization stage. The homogenization temperatures and salinity of FIs suggest basin brains as probable source of mineralizing fluids. The fluid inclusion studies, copper mineral association with abundant gangue minerals and the development of alteration halos, including argillic, silicic and propylitic zones, suggest that the Kushk-e-Bahram deposit is best compared to Chilean Manto-type deposits.

\section{Acknowledgements}

The authors wish to thank Mr Ehsan Haj Molla Ali and Mr Hossein Tahami (Hadid Gostar Sirjan Company) for financial and data support.

\section{References}

Abolipour, M., Rastad, E. \& Rashidnejad, N., 2015. Manto type copper mineralization in pyrobitumen-bearing porphyritic andesite, Kashkouieh district of Rafsanjan, Dehaj Sardoiye subzone. Geosciences 24, 123-144.

Afzal, P., Khakzad, A., Moarefvand, P., Rashidnejad Omran, N., Esfandiari, B. \& Fadakar Alghalandis, Y., 2010. Geochemical anomaly separation by multifractal modeling in Kahang (Gor Gor) porphyry system, Central Iran, Journal of Geochemical Exploration 104, $34-46$. 
Aghazadeh, M., Hou, Z., Badrzadeh, Z. \& Zhou, L., 2015. Temporal-spatial distribution and tectonic setting of porphyry copper deposits in Iran: constraints from zircon U-Pb and molybdenite Re-Os geochronology. Ore Geology Reviews 70, 385-406.

Alavi, M., 1994. Tectonics of the Zagros orogenic belt of Iran: new data and interpretations. Tectonophysics 229, 211-238.

Alipour-Asll, M., 2019. Geochemistry, fluid inclusions and sulfur isotopes of the Govin epithermal $\mathrm{Cu}-\mathrm{Au}$ mineralization, Kerman province, SE Iran. Journal of Geochemical Exploration 196, 156-172.

Alirezaei, A., Arvin, M. \& Dargahi, S., 2017. Adakite-like signature of porphyry granitoid stocks in the Meiduk and Parkam porphyry copper deposits, NE of Shahr-e-Babak, Kerman, Iran: Constrains on geochemistry. Ore Geology Reviews 88, 370-383.

Alizadeh, V., Momenzadeh, M. \& Emami, HM., 2013. Petrography, geochemistry, mineralogy, fluid inclusions and mineralization study of Varezg-Qayen copper deposit. Geosciences 22, 47-58.

Amidi, MA., Shahrabi, M. \& Navaei, Y., 2006. Geological map of Zavieh, 1: 100,000. Geological Survey of Iran.

Beane, RE. \& Bodnar, RJ., 1995. Hydrothermal fluids and hydrothermal alteration in porphyry copper deposits. [In:] Wahl, P.W. \& Bolm, J.G. (Eds): Porphyry Copper Deposits of the American Cordillera, Tucson, Arizona. Arizona Geological Society, 83-93.

Berberian, M. \& King, G.C.P., 1981. Towards a paleogeography and tectonic evolution of Iran. Canadian Journal of Earth Sciences 18, 210-265.

Bodnar, R.J., 1993. Revised equation and table for determining the freezing point depression of $\mathrm{H} 2 \mathrm{O}-\mathrm{NaCl}$ solutions. Geochimica Cosmochimica Acta 57,683-684.

Boric, R., Holmgren, C., Wilson, NSF. \& Zentilli, M., 2002. The Geology of the El Soldado Manto Type Cu (Ag) Deposit, Central Chile. [In:] Porter, T.M. (Ed.): Hydrothermal Iron Oxide Copper-Gold \& Related Deposits: A Global Perspective. PGC Publishing, Adelaide, 163-184.

Boveiri, M., Rstad, E., Kojima, S. \& Rashidnejad, N., 2013. Volcanic redbed-type copper mineralization in the Lower Cretaceous volcano-sedimentary sequence of the Keshtmahaki deposit, southern Sanandaj-Sirjan Zone, Iran. Journal of Mineralogy and Geochemistry 107-121.

Calagari, A.A., 2004. Fluid inclusion studies in quartz veinlets in the porphyry copper deposit at Sungun, East- Azarbaijan, Iran. Journal of Asian Earth Sciences 23, 179-189.

Campus, F., 1980. Distroto Minero Punta del cobre, modelo interpretative. Revista Geologica de Chile 11, 51-76.

Carrillo-Rosua, J., Boyce, A.J., Morales, S. \& Rodriguez, V.M., 2014. Extremely negative and inhomogeneous sulfur isotope signatures in Cretaceous Chilean Manto type $\mathrm{Cu}-(\mathrm{Ag})$ deposits, Coastal Range of central Chile. Ore Geology Reviews 56, 13-24.

Esmaeli, M., Lotfi, M. \& Nezafati, N., 2015. Fluid inclusion and stable isotope study of the Khalyfehlou copper deposit, Southeast Zanjan, Iran. Arabian Journal of Geosciences 8, 9625-9633.
Fazli, N., Ghaderi, M. \& Maghfouri, S., 2015. Eastern Narbaghi Manto type stratabound copper mineralization in Eocene volcano-sedimentary sequence, northeast Saveh. [In:] Iran $33^{\text {th }}$ National Geosciences Symposium, 10.

Ghaderi, M., Fazli, N., Yan, S., Lentz, D.R. \& Li, J.W., 2016. Fluid inclusion studies on North Narbaghi intermediate sulphidation epithermal Ag-Cu deposit, Urmia-Dokhtar magmatic arc, Iran. [In:] World Multidisciplinary Earth Sciences Symposium, Prague, 8.

Haas, J.I., 1971. The effect of salinity on the maximum thermal gradient of a hydrothermal system at hydrostatic pressure. Economic Geology 6, 940-946.

Haschke, M., Ahmadian, J., Murata, M. \& McDonald, I., 2010. Copper mineralization prevented by arc-root delamination during Alpine-Himalayan collision in central Iran. Economic Geology 105, 855-865.

Hezarkhani, A., 2006. Petrology of Intrusive rocks within the Sungun Porphyry Copper Deposit, Azerbaijan, Iran. Journal of Asian Earth Sciences 73, 326-340.

Imer, A., Richards, J. \& Muehlenbachs, K., 2016. Hydrothermal evolution of the Çöpler porphyry-epithermal $\mathrm{Au}$ deposit, Erzincan Province, central eastern Turkey, Economic Geology 111, 1619-1658.

Jebeli, M., Afzal, P., Pourkermani, M. \& Jafarirad, A., 2018. Correlation between rock types and Copper mineralization using fractal modeling in Kushk-e-Bahram deposit, Central Iran. Geopersia 8, 131-141.

Karami, K. \& Afzal, P., 2015. Application of multifractal modeling for separation of sulfidic mineralized zones based on induced polarization and resistivity data in the Ghare-Tappeh Cu deposit, NW Iran. Iranian Journal of Earth Sciences 7, 134-141.

Kesler, S.E., 2005. Ore-forming fluids. Elements 1, 13-18.

Kojima, S., Astudillo, J., Rojo, J., Trista, D. \& Hayashi, K., 2003. Ore mineralogy, fluid inclusion, and stable isotopic characteristics of stratiform copper deposits in the coastal Cordillera of northern Chile. Mineralium Deposita 38, 208-216.

Kojima, S., Trista, D., Guilera, A. \& Kenichiroayashi, H., 2009. Genetic aspects of the Manto type copper deposits based on geochemical studies of north Chilean deposits. Resource Geology 59, 87-98.

Maghfouri, S. \& Movahednia, M., 2015. Investigation of geology and mineralization of Abbas Abad copper deposit and camper with Manto type deposit. [In:] $18^{\text {th }}$ Symposium on Iranian Geosciences. Tarbiat Modares Univ. (in Persian with English abstract).

Maghfouri, S., Hosseinzadeh, M.R., Moayyed, M, Movahednia, M. \& Choulet, F., 2016. Geology, mineralization and sulfur isotopes geochemistry of the Mari $\mathrm{Cu}$ (Ag) Manto type deposit, northern Zanjan, Iran. Ore Geology Reviews 81, 10-22.

McInnes, B.I.A., Evans, N.J., Fu, F.Q., Garwin S., Belousova, E., Griffin, W.L., Bertens, A., Sukama, D., Permanadewi S., Andrew, R.L. \& Deckart, K., 2005. Thermal history analysis of selected Chilean, Indonesian, and Iranian Porphyry Cu-Mo-Au deposits. [In:] Porter, T.M. (Ed.): Super porphyry copper and gold deposits: A global perspective. PGC Publishing, Adelaide, 1-16.

McQuarrie, N., Stock, J.M., Verdel, C. \& Wernicke, B.P., 2003. Cenozoic evolution of Neotethys and implica- 
tions for the causes of plate motions. Geophysical Research Letters 30, 20-36.

Oyarzun, R., Ortega, L., Sierra, J., Lunar, R. \& Oyarzun, J., 1998. Cu, Mn, and Ag mineralization in the Quebrada Marquesa Quadrangle, Chile: The Talcuna and Arqueros districts. Mineralium Deposita 33, 547-559.

Rajabpour, S., Behzadi, M., Jiang, S., Rasa, I., Lehmann, B. \& Ma, Y., 2017. Sulfide chemistry and sulfur isotope characteristics of the Cenozoic volcanic-hosted KuhPang copper deposit, Saveh county, northwestern central Iran. Ore Geology Reviews 86, 563-583.

Ramdohr, P., 1980. The Ore Minerals and their Intergrowths. Pergamon Press, 1205 pp.

Ramirez, L.E., Palacios, C., Townley, B., Parada, M.A., Sial, A.N., Fernandez-Turiel, J.L., Gimeno, D., Garcia-Valles, M. \& Lehmann, B., 2006. The Mantos Blancos copper deposit: an upper Jurassic breccia-style hydrothermal system in the coastal range of northern Chile. Mineralium Deposita 41, 246-258.

Redmond, P.B., Einaudi, M.T., Inan, E.E., Landtwing, M.R. \& Heinrich, C.A., 2004. Copper deposition by fluid cooling in intrusion-centered systems: new insights from the Bingham porphyry ore deposit, Utah. Geology 32, 217-220.

Rezaei, S., Lotfi, M., Afzal, P., Jafari, M.R. \& Shamseddin Meigoony, M., 2015. Prospecting of copper and gold occurrences using multifractal modeling with index overlay integration in Saveh, Central Iran. Mineral Resources Management 31, 51-74.

Rezaei-Kahkhaei, M., Galindo, C., Pankhurst, R.J. \& Esmaeily, D., 2011. Magmatic differentiation in the calc-alkaline Khalkhab-Neshveh pluton, Central Iran. Journal of Asian Earth Sciences 42, 499-514.

Richards, J.P., 2015. Tectonic, magmatic, and metallogenic evolution of the Tethyan orogen: From subduction to collision. Ore Geology Reviews 70, 323-345.

Roedder, E., 1971. Fluid inclusion studies on the porphyry-type ore deposits at Bingham, Utah, Butte, Montana, and Climax, Colorado. Economic Geology 66, 98-118.

Roedder, E., 1984. Fluid inclusions. Mineral Society of America Reviews in Mineralogy 12, 644 pp.

Roedder, E., Bodnar, R.J., 1980. Geologic pressure determinations from fluid inclusion studies. Annu. Rev. Earth Planet. Sci. 8, 263.

Salehi, L. \& Rasa, I., 2016. Sulfur Isotopic Characteristics of the Chalcocite in Madan Bozorg Cu Deposits, Abbas Abad, NE Iran. [In:] $34^{\text {th }}$ National and the $2^{\text {nd }}$ International Geosciences Congress, Tehran, Iran.
Samani, B., 1998. Distribution, setting and metallogenesis of copper deposits in Iran. [In:] Porter, T.M. (Ed.): Porphyry and Hydrothermal Copper and Gold Deposits: A Global Perspective. PGC Publishing, Adelaide, 151-174.

Samani, B., 2003. Metallogeny of Manto copper deposits in Iran. [In:] $6^{\text {th }}$ Symposium of Geological Society of Iran, 8.

Shafiei, B., Haschke, M. \& Shahabpour, J., 2009. Recycling of orogenic arc crust triggers porphyry $\mathrm{Cu}$ mineralization in Kerman Cenozoic arc rocks, southeastern Iran. Mineralium Deposita 44, 265-283.

Shahabpour, J. \& Kramers, J.D., 1987. Lead isotope data from the Sarcheshmeh porphyry copper deposit, Iran. Mineralium Deposita 22, 278-281.

Shepherd, T.J., Rankin, A.H. \& Alderton, D.H.M., 1985. A Practical Guide to Fluid Inclusion Studies. Blackie \& Sons, Glasgow, 239 pp.

Simmons, S.F., White, N.C. \& John, D., 2005. Geological characteristics of epithermal precious and base metal deposits. Economic Geology 100, 485-522.

Ulrich, T., Gunther, D. \& Heinrich, C.A., 2002. The evolution of a porphyry Cu-Au deposit, based on LA-ICPMS analysis of fluid inclusions. Bajo de la Alumbrera, Argentina. Economic Geology 97, 1888-1920.

Wang, G.G., Ni, P., Wang, R.C., Zhao, K.D., Chen, H., Ding, J.Y., Zhao, C. \& Cai, Y.T., 2013. Geological, fluid inclusion and isotopic studies of the Yinshan $\mathrm{Cu}-\mathrm{Au}$ $\mathrm{Pb}-\mathrm{Zn}-\mathrm{Ag}$ deposit, south China: Implications for ore genesis and exploration. Journal of Asian Earth Sciences 74, 343-360.

Wilson, N.S.F., \& Zentilli, M., 2006. Association of pyrobitumen with copper mineralization from the Uchumi and Talcuna districts, central Chile. International Journal of Coal Geology 65, 158- 169.

Yao, J., Ni, P., Zhao, K.D. \& Wang, H.T., 2012. Evolution of ore-forming fluids of the Tongchang porphyry copper deposit, Dexing, NE Jiangxi province. Bulletin of Mineralogy Petrology and Geochemistry 31, 97-108 (in Chinese with English abstract).

Zarasvandi, A., Rezaei, M., Sadeghi, M., Lentz, D. \& Pourkaseb, H., 2015. Rare earth element signatures of economic and sub-economic porphyry copper systems in Urumieh-Dokhtar Magmatic Arc (UDMA), Iran. Ore Geology Reviews 70, 407-423.

Manuscript received: 17 February 2020 Revision accepted: 5 June 2020 